演題39は SPan-1 の臨床的検討であった。基準值の設定, 各種疾患 別の陽性率, 膵癌部位別の SPan-1 值, SPan-1 の有用性などについ て報告された。健常者群で女性が若干高值を示す傾向があるとの興味 梁い報告があったが, その原因については解明されていない. 今後の 研究課題であろう。

部会では, In Vitro 検査の演題数がいつも少ないようである. 会員 にIn Vitro 検榃を理解していたたくくためにも開発キットの検討だけ でなく, 日常検査での疑問点, 改善点などたくさんの発表を期待した い.

\section{放射線治療技術 I}

座長 横田典和 (高知医科大学)

40、不整形昭射野へのマルチリーフの応用（field factor の検討）

川崎医科大学附属病院中央放射線部

○大鼻 康・沼口健治・古城 剛

長瀬尚巳・成廣直正・赤澤裕二

吉田耕治・日地啓夫

〔目的〕 3 種類の等価照射野計算法で代表的不整形照射野の field factor を求め, 電離箱法で測定した值と比較し, 実用的な等価照射野 取得法を検討する。

[結果〕計算精度の面では， $\triangle \mathrm{SAR}$ 法が最も良く，照射野の形，工 ネルギーを問わず $00.7 \%$ 以内（測定值の $\mathrm{CV}=0.31 \%$ ）で一致した。 実用面では, $\sqrt{\mathrm{A}}$ 法や $\mathrm{A} / \mathrm{P}$ 法が簡便であるが, 照射野の形により, 特 に大きな open fieldでビーム中心軸近くまで遮蔽されるような場合 に, 誤差が大きくなることが示唆された。、マルチリーフによる不整形 照射野の等価照射野取得法に, $\sqrt{\mathrm{A}}$ 法を評価した先人の報告とは異な る結果を得た。

\section{1、不整形照射野へのマルチリーフの応用一皮成保護効果への影讳}

\section{川崎医科大学附属病院中央放射線部 ○成廣直正・沼口健治・古城 剛 長瀬尚巳・赤澤裕二・大皇 康 吉田耕治・日地啓夫}

(目的〕マルチリーフを不整形照射に利用する場合の有用性を，皮 成保護効果から検討する。

[方法〕シャローチェンバにより,マルチリーフ法と鉛ブロック法 の RSD (relative surface dose) を求める。

【結果〕鉛ブロック法の RSD 増加は，そのほとんどがトレイから の二次電子の寄与によるものであった．鉛ブロック法の RSD 增加は マルチリーフ法に比へてて, $4 \mathrm{MV}$ で最大 1.74 倍, $10 \mathrm{MV}$ で最大 2.11 倍 に達した。

〔まとめ〕マルチリーフ法は皮成保護効果が保たれ，自動セットア ップや照合の利用で安全性や再現性が高められ，極めて有用と思われ る. 反面, リーフの機能や精度が重要となるが, 現時点では十分でな いのでメーカにより一層の努力を望みたい。

42. MEVATRON 6300 における非対称コリメータの物理評価 広島大学医学部附属病院

○木口雅夫・玖島利男・石風吕実 池田俊貴・斉藤温巳

MEVATRON 6300 の非対称絞り (half field) を用いて, 照射野形 状の違いによる出力線量 $\mathrm{F}_{\mathrm{A}}(\mathrm{A})$, 深部線量 PDD, TPR 平坦度につ いて対称絞りの照射野と比較検討した。非対称絞りにおいて PDD は，照射野 $10 \times 10 \mathrm{~cm}^{2}$ 以上で $1 \sim 2 \%$ 低く，TPR は，照射野 $10 \times 10$ $\mathrm{cm}^{2}$ 以上の深さ $10 \mathrm{~cm}$ て $1 \%, 15 \mathrm{~cm}$ 以上で $2 \sim 5 \%$ 低い値を示し た。 $F_{\mathrm{A}}(\mathrm{A})$ は照射野の大きさによる変化率が大きく, 2〜 7\%高い 值を示した。また，矩形照射野では短軸 $10 \mathrm{~cm}$ 以下で $F_{A}(A)$ は低い 値を示した。これらは, 非対称照射野において, 測定点が LR 方向に $2 \sim 10 \mathrm{~cm}$ 偏位寸, フラットニングフィルタ厚も異なるため変化が生 じたと考える. 線量評価をする際, 測定点を線量の安定した照射野中 心で評価すれば，充分臨床応用可能と考える。

43. 非密暗型電子線アプリケータの特性

川崎医科大学附属病院中央放射線部

○長瀬尚巳・沼口健治・古城 剛 成廣直正・赤澤裕二・大畠 康 吉田耕治・日地啓夫
【目的〕電子線不整形照射野の output factor を, 非密着型アプリ ケータを用いて検討する。

〔方法〕電離箱で不整形照射野 8 種類の output factor を測定し, square root 変法による計算值と比較する.

〔結果〕 open field に対する不整形照射野の output factor 減少は, $4 \mathrm{MeV}: 3 \%$ 以内, $9.15 \mathrm{MeV}: 1 \%$ 以内であった. また, square root 変法は, 測定值に対して $\pm 1 \%$ 以内で output factor を求めることが できた.

〔まとめ〕非密着型アプリケータの SSD 延長法は密着型に比べて， 線量分布や output への影響が少なく, セットアップの容易さ, 安全性 の面加有用な使用法と考えられる。 また，不整形の output factor は square root 変法により精度良く求め得た。

\section{座長集約}

近年の放射線治療では, 治療計画に CT 画像, あるいは MR 画像な どが積極的に活用され，より高精度な照射技術が求められている。 そ して照射野に扔いては, 様々な照射野形状が求められるのも当然の事 である。このセクションでは, こういった要求に応えるべく, 不整形 照射, half field 法による照射に関しての報告がされた。

演題40では，不整形照射の線量モニターュニットの計算精度を向上 させるための有効な照射野係数計算方法が示された. しかし, 手計算 で行っているとのことで, 煩雑な計算を簡便化するためにも, 今後, 電算機による算出を期待する。

演題41では，不整形照射野のトリミングに扔いて，従来の鉛ブロッ ク法に比べての, マルチリーフ法の総合的な有用性が示された。、ル チリーフを有効に使用するには, 機能の向上, 精度管理が重要な課題 のようである。

演題42は，対称絞りと非対称絞りの線量特性を比較した報告であ る. half field 法を必要とする照射も多く, 線量特性を理解した上で照 射を行うべきであり，興味ある報告であった。

演題 $43 て ゙ は$, 電子線の不整形照射野の照射野係数についての有効な 算出が示された.演者はこれまで非密着型アプリケータの特性につい てシリーズで報告しているが，今後このタイプが主流になると思わ れ，非常に興味ある報告であった。今後のさらなる報告を期待する. 放射線治療技術 II

\section{4. 電子線エネルギー低隇におけるX線混入率の検討} ースキャタリングホイールの材貿についてー

岡山大学医学部附属病院中央放射線部 ○村誠一・稲村圭司・田原誠司 江草具視・三上泰隆

岡山大学医療技術短期大学部 中桐義忠・三宅英昭

[目的〕菌状息肉症などの治療は，5 MeV 以下の低エネルギーの 電子線による全身皮满照射治療が行われている。この最適エネルギー が得られない装置において，今回 Scattering foil の材質を変化させ て電子線エネルギーの低隇化と,X線混入率について基礎的検討を行 つた.

〔結果〕電㸚箱を用いた測定から, Scattering foil の材質をアクリ ル,カーボン, 塩化ビニール，アルミニューム，銅，鉛などに交換す ることにより，10 MeV の電子線を $5 \mathrm{MeV}$ 程度のエネルギーに低減 が可能となった。

また,アクリルやカーボンなどの低原子番号物質を利用することて $\mathrm{X}$ 線混入率の低隇も可能であった。平坦度については変化を認めなか った.

45. 乳房接線照射における線量評価（患側乳房の線量分布）

広島大学医学部附属病院放射線部

○河野信吾・玫島利男・木口雅夫 斉藤温己

乳房温存療法の乳房接線照射において均一で正確な患側乳房内線 量分布を得ることを目的として15症例の CT 画像で線量分布計算を 行い, 線量分布の均一性を視覚的にスコア化して評価し各種治療パラ メー夕と比較した. また基準点のアイソセンター線量と標的容積内の 平均線量・最大線量を比較して線量評価誤差についても検討した。 ウ エッジに関しては全症例とも15度が良好であり30度は照射野内の肺 